\title{
Molecular features of the complementarity determining region 3 motif of the T cell population and subsets in the blood of patients with chronic severe hepatitis $B$
}

\author{
Jiezuan Yang ${ }^{1}$, Jianqin $\mathrm{He}^{1}$, Haifeng Lu' ${ }^{1}$ Li Wei ${ }^{1}$, Sujun $\mathrm{Li}^{2}$, Baohong Wang ${ }^{1}$, Hongyan Diao ${ }^{1}$ and Lanjuan $\mathrm{Li}^{i^{*}}$
}

\begin{abstract}
Background: $T$ cell receptor (TCR) reflects the status and function of T cells. We previously developed a gene melting spectral pattern (GMSP) assay, which rapidly detects clonal expansion of the T cell receptor $\beta$ variable gene (TCRBV) in patients with HBV by using quantitative real-time reverse transcription PCR (qRT-PCR) with DNA melting curve analysis. However, the molecular profiles of TCRBV in peripheral blood mononuclear cells (PBMCs) and CD8 ${ }^{+}$, CD8 ${ }^{-}$cell subsets from chronic severe hepatitis B (CSHB) patients have not been well described.

Methods: Human PBMCs were separated and sorted into CD8 ${ }^{+}$and $C D 8^{-}$cell subsets using density gradient centrifugation and magnetic activated cell sorting (MACS). The molecular features of the TCRBV CDR3 motif were determined using GMSP analysis; the TCRBV families were cloned and sequenced when the GMSP profile showed a single-peak, indicative of a monoclonal population.

Results: The number of skewed TCRBV in the $\mathrm{CD}^{+}$cell subset was significantly higher than that of the CD8 $8^{-}$cell subset as assessed by GMSP analysis. The TCRBV11 and BV7 were expressed more frequently than other members of TCRBV family in PBMCs and CD8 ${ }^{+}, \mathrm{CD}^{-}$subsets. Also the relatively conserved amino acid motifs were detected in the TCRBV22, BV18 and BV11 CDR3 in PBMCs among patients with CSHB.

Conclusions: The molecular features of the TCRBV CDR3 were markedly different among PBMCs and CD8 ${ }^{+}, \mathrm{CD}^{-}$ cell subsets derived from CSHB patients. Analysis of the TCRBV expression in the CD8 ${ }^{+}$subset was more accurate in assessing the status and function of circulating T cells. The expression of TCRBV11, BV7 and the relatively conserved CDR3 amino acid motifs could also help to predict and treat patients with CSHB.
\end{abstract}

\section{Background}

Hepatitis B virus (HBV) infection remains a global health problem with more than 350 million chronically infected people worldwide; approximately 1 million people die from HBV-related diseases every year [1]. Notably, chronic severe hepatitis B (CSHB) is associated with a high mortality rate; however, its pathogenesis is not well understood. Although antiviral treatment can suppress viral replication, it does not promote complete clearance of HBV. Therefore, clarifying the pathogenesis

\footnotetext{
* Correspondence: ljil@zju.edu.cn

${ }^{1}$ State Key Laboratory for Diagnosis and Treatment of Infectious Diseases, First Affiliated Hospital, College of Medicine, Zhejiang University, Hangzhou 310003, China

Full list of author information is available at the end of the article
}

of hepatitis B is particularly important. HBV-related pathology is mainly mediated by the immune response to infection $[2,3]$. HBV-specific cytotoxic T cell (CTL) recognition and killing of infected hepatocytes is believed to be a key factor in infection-associated liver damage.

$\mathrm{T}$ cell responses can be directed towards a variety of specific antigens due to the diversity of the $T$ cell receptor (TCR) repertoire. $\mathrm{T}$ cells of different specificity express different complementarity determining region 3 (CDR3) that vary in length or sequence [4,5]. Measuring the frequency of specific CDR3 sequences can reflect the degree of $\mathrm{T}$ cell clonal expansion and provide some understanding of $\mathrm{T}$ cell function.

\section{C) Biomed Central}


In recent years, exploring TCR expression during chronic viral infections has become a hot topic in the field of infectious disease. Furthermore, this is the basis of applied research to characterize TCR profiles in a variety of diseases and of studies that have shown that $\mathrm{T}$ cells with transformed genes can be used to treat advanced leukemia, a strategy that has achieved results in the clinic [6]. In this study, lymphocyte subsets were sorted using magnetic bead separation technology, and the distribution features of the $\mathrm{T}$ cell receptor $\beta$ variable gene (TCRBV) CDR3 in PBMCs from patients with CSHB were investigated. Additionally, the CDR3 motif expressed in $\mathrm{CD}^{+}$and $\mathrm{CD} 8^{-}$cell subsets was also characterized.

\section{Materials and methods}

\section{Enrollment of patient population}

Forty-two patients with CSHB admitted to the Department of Infectious Disease, First Affiliated Hospital, College of Medicine, Zhejiang University, between September 2010 and March 2011, were included in the present study. All subjects had been HBsAg-positive for at least 12 months. Co-infection with human immunodeficiency virus (HIV), hepatitis A virus (HAV), hepatitis $\mathrm{C}$ virus (HCV), hepatitis D virus (HDV), and hepatitis $\mathrm{E}$ virus (HEV) were excluded by laboratory testing. The patients with CSHB had a serum alanine aminotransferase (ALT) level $>40 \mathrm{IU} / \mathrm{L}$, a total bilirubin $(\mathrm{TBiL})$ level $>170$ $\mu \mathrm{mol} / \mathrm{L}$, and a plasma prothrombin activity (PTA) < $40 \%$ [7]. Patient characteristics at the time of the study are shown in Table 1. Peripheral blood samples were collected after informed consent was obtained from each patient and healthy control. This study was conducted according to the guidelines of the Declaration of Helsinki; the Zhejiang University medical ethics committee approved all procedures involving human subjects.

Table 1 Clinical features of the CSHB patients at entry to the study

\begin{tabular}{ll}
\hline Characteristics & All patients $(\mathbf{n}=\mathbf{4 2})$ \\
\hline Sex (male/female) & $29 / 13$ \\
Mean age (in years)† & $45.6 \pm 8.3$ \\
Duration of infection (years) $\dagger$ & $14.2 \pm 9.1$ \\
ALT level (IU/L)† & $68.8 \pm 75.3$ \\
Total bilirubin level $(\mu \mathrm{mol} / \mathrm{L}) \dagger$ & $363.2 \pm 173.5$ \\
HBV DNA (lg, copies/mL)† & $4.5 \pm 1.6$ \\
HBeAg-positive patients $\neq$ & $16(38.1 \%)$ \\
HBV genotypes & $15 B, 27 C$ \\
\hline
\end{tabular}

CSHB, chronic severe hepatitis B; ALT: alanine amino transferase; Normal values: $A L T, \leq 40 \mathrm{IU} / \mathrm{L}$; total bilirubin, $\leq 21 \mu \mathrm{mol} / \mathrm{L}$. tData are expressed as mean \pm SD; $\neq$ Data are expressed as no. (\%).

\section{Study design}

GMSP analyses were performed using PBMCs from 27 patients with $\mathrm{CSHB}$, and PBMCs from 15 patients were sorted into $\mathrm{CD}^{+}$cells and $\mathrm{CD} 8^{-}$cells (i.e., the remaining cell fraction) using immunomagnetic beads, then the TCRBV profile was assessed. The skewed rates of each biased TCRBV families were calculated, and the monoclonal TCRBV was cloned and sequenced. Additionally, the relationship among the skewed TCRBV families of PBMCs and $\mathrm{CD}^{+}, \mathrm{CD}^{-}$cell subsets was analyzed.

\section{Biochemical and serological markers evaluation}

Liver function was assessed by serum ALT, AST, and TBiL levels. These assays were determined using an automatic biochemical analyzer (HITACHI 7600, Japan). The qualitative determination of HBV markers ( $\mathrm{HBsAg} /$ anti-HBs, HBeAg/anti-Hbe and anti-HBc) and other biochemical and serological markers was performed in the Central Clinical Laboratory of our unit.

\section{Quantification and determining genotype of HBV DNA}

The serum HBV DNA level was quantified using a realtime fluorescence quantitative commercial kit (Shenzhen PG Biotech, Shenzhen, China) with a lowest limit of detection equal to 500 viral genome copies $/ \mathrm{mL}$, and the HBV genotypes were determined as reported in an earlier study [8].

PBMCs separated, $\mathrm{CD}^{+}$cell sorted and purity assessment Peripheral venous blood samples were obtained after liver disease was diagnosed, prior to anti-viral treatment. PBMCs from 42 CSHB patients were isolated from fresh EDTAK $_{2}$ anti-coagulated blood using Ficoll-Paque (CEDARLANE, Netherlands) density gradient centrifugation. For 15 samples, $\mathrm{CD} 8^{+}$cells were positively selected from PBMCs using anti-CD8 antibody-coated magnetic beads according to the directions of the manufacturer (Dynal Biotech, Norway), and the remaining fraction was depleted of $\mathrm{CD}^{+}$cells (CD8 ${ }^{-}$cells). Purity of the separated subsets were tested by FCM analysis using PE- labeled anti- CD8 and FITC- labeled anti$\mathrm{CD} 4$ monoclonal antibodies, and the $\mathrm{CD}^{+}$cell population was found to be $>95 \%$ pure (results not shown).

\section{CDNA synthesis and real-time PCR}

Total RNA was extracted from $\mathrm{PBMCs}\left(\mathrm{CD} 8^{+}\right.$or $\mathrm{CD}^{-}$ cell subsets) using a SV Total RNA Isolation System (Promega, USA) according to the manufacturer's directions. RNA purity and concentration were determined by the optical density (OD) assessed using a spectrophotometer (Bio-rad, USA). Total RNA was immediately reverse transcribed to cDNA using the RevertAid ${ }^{\mathrm{TM}}$ First Strand cDNA Synthesis Kit (MBI, EU). Briefly, 1 5 $\mu \mathrm{g}$ total RNA was reverse transcribed with OligodT18 as 
primer in a $20 \mu \mathrm{L}$ reaction volume. cDNA was diluted 1:2 before being used as a template for real-time PCR with SYBR green dye. The GoTaq ${ }^{\circledR}$ qPCR Master Mix (Promega, USA) was selected as the PCR kit, and the real-time PCR (dye method) reaction parameters were as follows: 2 min of incubation at $95^{\circ} \mathrm{C}$ to activate the GoTaq enzyme, followed by 45 cycles of denaturation at $95^{\circ} \mathrm{C}$ for $15 \mathrm{~s}$, annealing at $56^{\circ} \mathrm{C}$ for $20 \mathrm{~s}$, and extension at $72^{\circ} \mathrm{C}$ for $25 \mathrm{~s}$, and the fluorescence signal was acquired at the end of every cycle. At the end, a final extension was performed at $72^{\circ} \mathrm{C}$ for $8 \mathrm{~min}$, following the gene melting analysis. The experiment details were described in our previous study [9].

\section{Skewed clonal expansion of TCRBV gene families}

After the gene melting step was complete, the melting curve for the 24 TCRBV gene families was obtained. The melting peak can be determined by plotting the negative first derivative of the decrease in fluorescence signal versus temperature $(-\mathrm{dF} / \mathrm{dT})$ versus temperature $(\mathrm{Tm})$; this technique is called the Gene Melting Spectral Pattern (GMSP) analysis as we previously reported [9]. The skewed clonal expansion was defined using the profile of each GMSP image displayed by the software (Opticon Monitor 3.0) attached to the MJ Opticon 2 DNA engine (Bio-rad, USA), and included two categories: 1) "Oligoclonal expansion", appearing as a main peak associated with other small peaks on the GMSP, and a small peak with a height less than half the height of the main peak; and 2) the "Monoclonal" category, with only one main peak, and a very short small peak or no additional peak.

\section{Cloning and sequencing}

When the GMSP analysis of a sample demonstrated a TCRBV family monoclonal profile (single peak), the corresponding TCRBV gene family was selected for cloning and sequencing to characterize and determine the degree of homogeneity within the CDR3 region. The brief steps were following, the cDNA of the TCRBV gene family was amplified again using GoTaq DNA polymerase (Promega, USA) under the conditions: preincubation at $95^{\circ} \mathrm{C}$ for $2 \mathrm{~min}$ to denature target cDNA, $95^{\circ} \mathrm{C}$ for $40 \mathrm{~s}$, annealing at $56^{\circ} \mathrm{C}$ for $40 \mathrm{~s}$, and extension at $72^{\circ} \mathrm{C}$ for $60 \mathrm{~s}$, for 40 cycles of amplification. PCR products were separated using $2 \%(0.5 \%$ Tris-buffered EDTA) agarose gels (FMV BioProducts, Rockland, ME), excised, and purified using a QIAEX gel extraction kit (Qiagen, German). Purified products were ligated into pGEMT-T easy vector using the pGEM-3Z Cloning Kit (Promega, USA) according to the manufacturer's instructions. The plasmid DNA was sequenced in an ABI3730 DNA Sequencer (Applied Biosystems, USA). The results sequenced were analyzed against a standard TCRBV gene database http://www.imgt.org.

\section{Statistical analysis}

Differences in data between two groups were examined using a $\chi^{2}$-test or Student's $t$-test, with a $P<0.05$ considered significant. Statistical analysis was performed using SPSS 16.0 software (SPSS Inc., Chicago, USA).

\section{Results \\ Skewed TCRBV repertoire within total PBMCs and $\mathrm{CD}^{+}$, CD8- subsets}

The $\mathrm{CD}^{+}$and $\mathrm{CD}^{-} \mathrm{PBMC}$, which were mostly $\mathrm{CD} 4^{+}$, were obtained using magnetic sorting. The TCRBV CDR3 profiles were compared between two sorted cell populations (15 samples sorted) and the 27 PBMCs populations isolated from patients with CSHB. Among the three groups of cell populations evaluated, the TCRBV families in the $\mathrm{CD}^{+}$cells from patients contained a greater number of skewed-clonally expanded TCRBV families. The average number of skewed (oligoclonal and monoclonal) TCRBV families in the CD8PBMC fraction was lower than the PBMCs and the CD8 ${ }^{+}$subset $(P<0.01)$, and there was no significantly difference between the two latter groups $(P>0.05)$. Additionally, there were a higher number of patients with a normal TCRBV pattern in the $\mathrm{CD}^{-}$fraction compared to the other two cell fractions (Table 2). There was a greater number of skewed clone expansion of TCRBV families expressed in the $\mathrm{CD}^{+}$PBMC compared to the CD8 ${ }^{-}$cells (Table 3 , Figure 1 ).

\section{GMSP profile of monoclonal TCRBV in total PBMCs and $\mathrm{CD}^{+}, \mathrm{CD}^{-}$subsets}

The profile of the TCRBV families expressed by total PBMCs and $\mathrm{CD}^{+}, \mathrm{CD}^{-}$fractions was determined using GMSP analysis. Although, the number of single-peaks and biased-peaks for the 24 TCRBV families detected from the three cell populations (total PBMCs and $\mathrm{CD}^{+}$, $\mathrm{CD}^{-}$cell subsets) differed among the CSHB patients, the two skewed TCRBV gene families (BV7, BV11) were more prevalent than other TCRBV families (Table 2 and 3). A representative GMSP profile of a monoclonal TCRBV expressed in PBMCs and in the $C D 8^{+}$and $C D 8^{-}$ subsets is shown in Figures 2 and 3, respectively.

\section{TCRBV CDR3 amino acid motifs in total PBMCs and $\mathrm{CD}^{+}$,} CD8- subsets

The monoclonal expansion of TCRBV CDR3 gene families were cloned, sequenced, and translated to corresponding amino acid sequences. The representative amino acid sequences of the TCRBV CDR3 from PBMCs and $\mathrm{CD}^{+}$and $\mathrm{CD}^{-}$subsets from patients with CSHB are shown in Table 4 and 5. We found that, among different CSHB patients, the monoclonal expansion of TCRBV CDR3, such as BV22 (DLGVAQ with BJ2.7), BV18 (RTGDTEA with BJ1.1) and BV11 (AGEL 
Table 2 The frequency of skewed TCRBV in $\mathrm{CD8}^{+}$and $\mathrm{CD8}^{-}$cells (PBMCs excluding CD8 ${ }^{+}$cell) and PBMCs from patients with CSHB $^{\text {a }}$

\begin{tabular}{|c|c|c|c|}
\hline TCRBV families & $\mathrm{CD}^{+}$cell Incidence $(\%)^{\mathbf{b}}$ & $\mathrm{CD}^{-}$PBMC Incidence $(\%)^{\mathrm{b}}$ & Total PBMCs Incidence (\%) \\
\hline 1 & 2 & 0 & 3 \\
\hline 2 & $4(28.6)$ & 1 & 4 \\
\hline 3 & 3 & 0 & 4 \\
\hline 4 & 3 & 3 & 6 \\
\hline 5.1 & $4(28.6)$ & 3 & $7(28)$ \\
\hline 5.2 & $5(35.7)$ & 1 & 4 \\
\hline 6 & 3 & 0 & 4 \\
\hline 7 & $4(28.6)$ & $5(38.5)$ & $9(36)$ \\
\hline 8 & 2 & 0 & $7(28)$ \\
\hline 9 & 2 & 0 & 6 \\
\hline 10 & 0 & 1 & 2 \\
\hline 11 & $9(64.3)$ & $9(69.2)$ & $15(60)$ \\
\hline 12 & $5(35.7)$ & 2 & 6 \\
\hline 13.1 & 3 & 1 & $7(28)$ \\
\hline 13.2 & $5(35.7)$ & 0 & $7(28)$ \\
\hline 14 & 2 & 0 & 3 \\
\hline 15 & 2 & 1 & 2 \\
\hline 16 & 3 & 0 & 3 \\
\hline 17 & $5(35.7)$ & 2 & 5 \\
\hline 18 & $5(35.7)$ & 1 & $8(32)$ \\
\hline 19 & 0 & 0 & 1 \\
\hline 20 & $4(28.6)$ & $4(30.1)$ & 4 \\
\hline 21 & $4(28.6)$ & 1 & 3 \\
\hline 22 & $6(42.9)$ & 3 & 5 \\
\hline 23 & 1 & 2 & 5 \\
\hline 24 & 3 & 1 & 1 \\
\hline $\begin{array}{l}\text { Total no. of skewed } \vee \beta \\
\text { (average ratio for a case) }\end{array}$ & $89(6.36)^{c, d}$ & $41(3.15)^{c}$ & $131(5.24)^{c, d}$ \\
\hline $\begin{array}{l}\text { No. of patients examined } \\
\text { with normal pattern (ratio, \%) }\end{array}$ & $1(6.67)^{\mathrm{e}}$ & $2(13.33)^{\mathrm{e}}$ & $2(7.41)^{\mathrm{e}}$ \\
\hline No. of patients examined & 15 & 15 & 27 \\
\hline
\end{tabular}

${ }^{a}$ The number of TCRBV gene families showing skewed-clone expansion (oligoclonal or monoclonal) is summarized in patients with CSHB.

${ }^{\mathrm{b}}$ The number of samples showing a skewed-clone expansion in total detected samples (percentages of each TCRBV skewed-clone expansion). Samples with normal GMSP (no skewed-clone expansion pattern) are excluded in the percentage calculation.

${ }^{\mathrm{C}}$ The average expansion rate of TCRBV gene families was lower in CD8- PBMC (depleted CD8 ${ }^{+}$cells) than in other two cell populations ( $P<0.01$ by $\chi^{2}$ test).

${ }^{\mathrm{d}}$ There was no significant difference between the two groups $\left(P>0.05\right.$ by $\chi^{2}$ test). Sample with normal GMSP (no skewed-clone expansion pattern) are excluded in the average ratio calculation.

'The incidence of the normal GMSP was significantly higher in $\mathrm{CD}^{-}$PBMC (depleted CD8 ${ }^{+}$cells) than in other two cell populations $\left(P<0.01\right.$ by $\chi^{2}$ test).

with BJ2.2 or VYNEQ with BJ2.1), in PBMCs was similar. However, when we compared the monoclonal expansion of TCRBV CDR3 in the $\mathrm{CD}^{+}$and $\mathrm{CD}^{-}$cell subsets, the amino acid sequence of TCRBV18 CDR3, (RTGDTEA with BJ1.1), was similar to PBMCs, as was the sequences of TCRBV11 (AGEL with BJ2.2 or VYNEQ with BJ2.1) and TCRBV5.2 (LTAGAYTGEL with BJ2.2).

\section{Discussion}

HBV infects a narrow host range, and the lack of ideal animal models or the efficient cell culture system greatly limits the study of the HBV-specific immune response
[10]. In recent years, research results show that the HBV antigen-induced cellular immune response necessary for viral clearance, especially the activity of HBVspecific CTL, also mediates HBV-associated liver inflammation and damage $[11,12]$.

$\mathrm{T}$ lymphocytes are composed of mainly $\mathrm{CD} 4^{+}$and $\mathrm{CD}^{+}$cells. There are characteristic TCR molecular chains expressed on the surface of $\mathrm{T}$ cells. In peripheral blood from healthy donors, the TCR of more than $95 \%$ of $\mathrm{T}$ cells is composed of alpha and beta chain heterodimers, i.e., $\alpha \beta \mathrm{T}$ cells [13]. Each $\mathrm{T}$ cell clone expresses a unique TCR that recognizes antigen-derived peptide bound to major histocompatibility complex (MHC), 
Table 3 GMSP assay-generated profile of skewed TCRBV gene families in CD8 ${ }^{+}$and CD8- cells in patients with CSHB

\begin{tabular}{|c|c|c|c|c|}
\hline \multirow[t]{2}{*}{ Patients no. } & \multicolumn{2}{|l|}{$\mathrm{CD8}^{+}$cells } & \multicolumn{2}{|c|}{$\mathrm{CD8}^{-}$cells } \\
\hline & Skewed TCRBV & Monoclone & Skewed TCRBV & Monoclone \\
\hline 1 & $3,5.2,7,13.1,18,20$ & $7,13.1$ & 7,11 & 7,11 \\
\hline 2 & $5.1,5.2,7,11,12,21,22,24$ & 11 & None & None \\
\hline 3 & $3,5.1,17,20,23$ & None & $2,7,11,20$ & 11,20 \\
\hline 4 & $4,5.2,11,12,18,21,22$ & 11 & 7,11 & None \\
\hline 5 & $2,13.2,15,16$ & 2,16 & $4,13.1$ & None \\
\hline 6 & $3,5.2,17,22$ & 17 & $5.1,11,17,22,23$ & 11 \\
\hline 7 & $4,6,8,11,12$ & 11 & $4,7,11$ & $4,7,11$ \\
\hline 8 & None & None & None & None \\
\hline 9 & $6,8,11,13.1,13.2,14,16,22$ & $11,13.1$ & $5.1,11,17,22,23$ & 11 \\
\hline 10 & $9,11,13.1,13.2,16,17,21,22,24$ & $11,13.2$ & $5.1,12,20$ & None \\
\hline 11 & $2,5.2,9,11,12,14,15,18$ & $5.2,11,18$ & $11,20,24$ & 11,24 \\
\hline 12 & $3,7,11,13.1,20,21$ & $7,11,20$ & 4 & 4 \\
\hline 13 & $2,5.1,6,13.2,17,18,22,24$ & 6,17 & $10,11,15,22$ & 11 \\
\hline 14 & $1,4,7,11,17,18$ & 11,18 & $5.2,7,11,18,20$ & 11,18 \\
\hline 15 & $2,5.2,12,13.2,20$ & None & 12,21 & None \\
\hline Total no. of altered (skewed) TCRBV families (no. of patients) & $89(15)^{\mathrm{a}}$ & $22(15)^{b}$ & $41(15)^{a}$ & $15(15)^{b}$ \\
\hline
\end{tabular}

a The rate of skewed TCRBV families was higher in $\mathrm{CD}^{+}$cells than in $\mathrm{CD} 8^{-}$cells $\left(P<0.01\right.$ by $\chi^{2}$ test). ${ }^{\mathrm{b}}$ The monoclonal rate was not significantly different between the two groups $\left(P>0.05\right.$ by $\chi^{2}$ test).

leading to $\mathrm{T}$ cell activation, proliferation, and effector function. The TCR has three complementary determining regions (CDR1, CDR2 and CDR3). CDR3 is the key determinant of $\mathrm{T}$ cell antigen specificity and mediates $\mathrm{T}$ cell diversity $[4,14]$. Therefore, analysis of the CDR3 profile reflects changes in the $\mathrm{T}$ cell population stimulated by a specific antigen $[15,16]$. This may aid in determining the effectiveness of the $\mathrm{T}$ cell response. For analysis of the TCR repertoire, the $\beta$ chain is often preferred because of the lower number of gene families

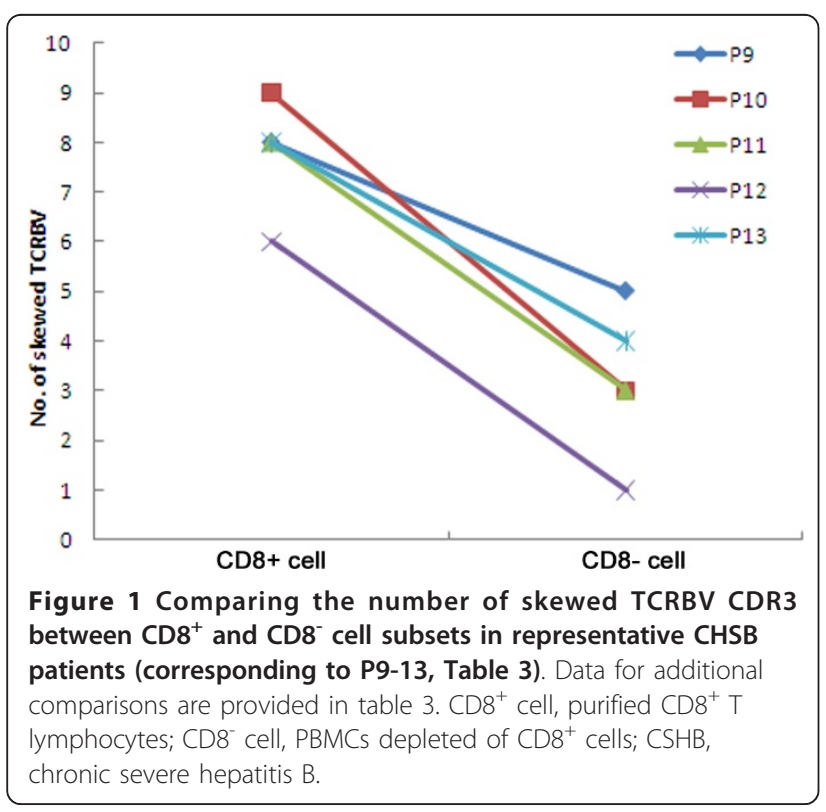

associated even though a higher overall sequence variability of sequence compared to the $\alpha$-chain has been reported [17].

Several approaches have been used to determine the expansion of TCRBV subgroups including Northern blotting, semi-quantitative PCR using radioisotope-conjugated probes [18], or fluorescence activated cell sorting (FACS) using fluorochrome-conjugated monoclonal antibodies (mAbs) specific to TCRBV subgroups [19] or direct quantification and characterization of $\mathrm{CD}^{+} \mathrm{T}$ cells using tetramer staining and intracellular cytokine staining. At present, the spectratyping (immunoscope) based on PCR was developed as the current standard in TCRBV repertoire analysis $[4,16]$. However, these approaches are susceptible to cross-contamination, laborious, and time consuming because they require PCR amplification, isolation of individual bands based on DNA size, and purification, followed by repeated cloning and sequencing.

Recently, quantitative real-time reverse transcription PCR (qRT-PCR) has become a widely accepted method for rapid and reproducible quantification of gene expression. Most previous attempts to quantify TCRBV expression using qRT-PCR have utilized one primer directed at the gene encoding the TCR constant region of the beta chain (BC) and another primer or fluorogenic probe directed towards the gene encoding the beta chain variable region (BV) [20-22]. In the current study, we examined the molecular features of the CDR3 motif from isolated PBMCs and $\mathrm{CD}^{+}$and $\mathrm{CD}^{-}$subsets from patients with CSHB using GMSP analysis. The 


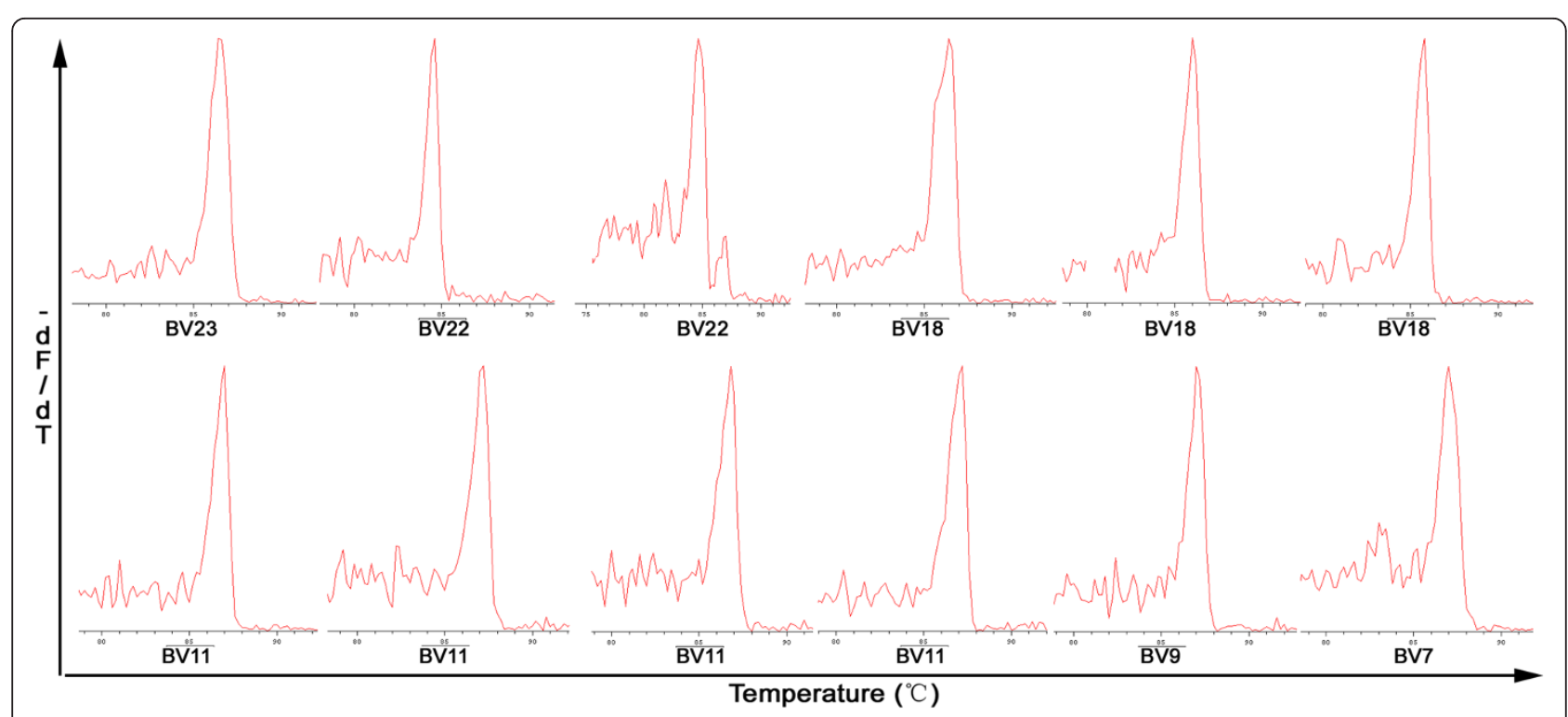

Figure 2 Representative GMSP with a single-peak (monoclonal expansion) of TCRBV in the PBMCs from patients with CSHB. The TCRBV gene families shown above in the top graphs correspond to P69 (BV23), P90 (BV22), P75 (BV22), P90 (BV18), P75 (BV18), and P105 (BV18); the TCRBVs shown on the bottom graphs correspond to P107 (BV11), P131 (BV11), P83 (BV11), P71 (BV11), P69 (BV9) and P172 (BV7). The corresponding amino acid sequences are shown in Table 4 . The melting temperature is on the $\mathrm{X}$-axis of each plot. The negative first derivation of the decrease in fluorescence versus temperature $(-d F / d T)$ is shown on the $y$-axis.

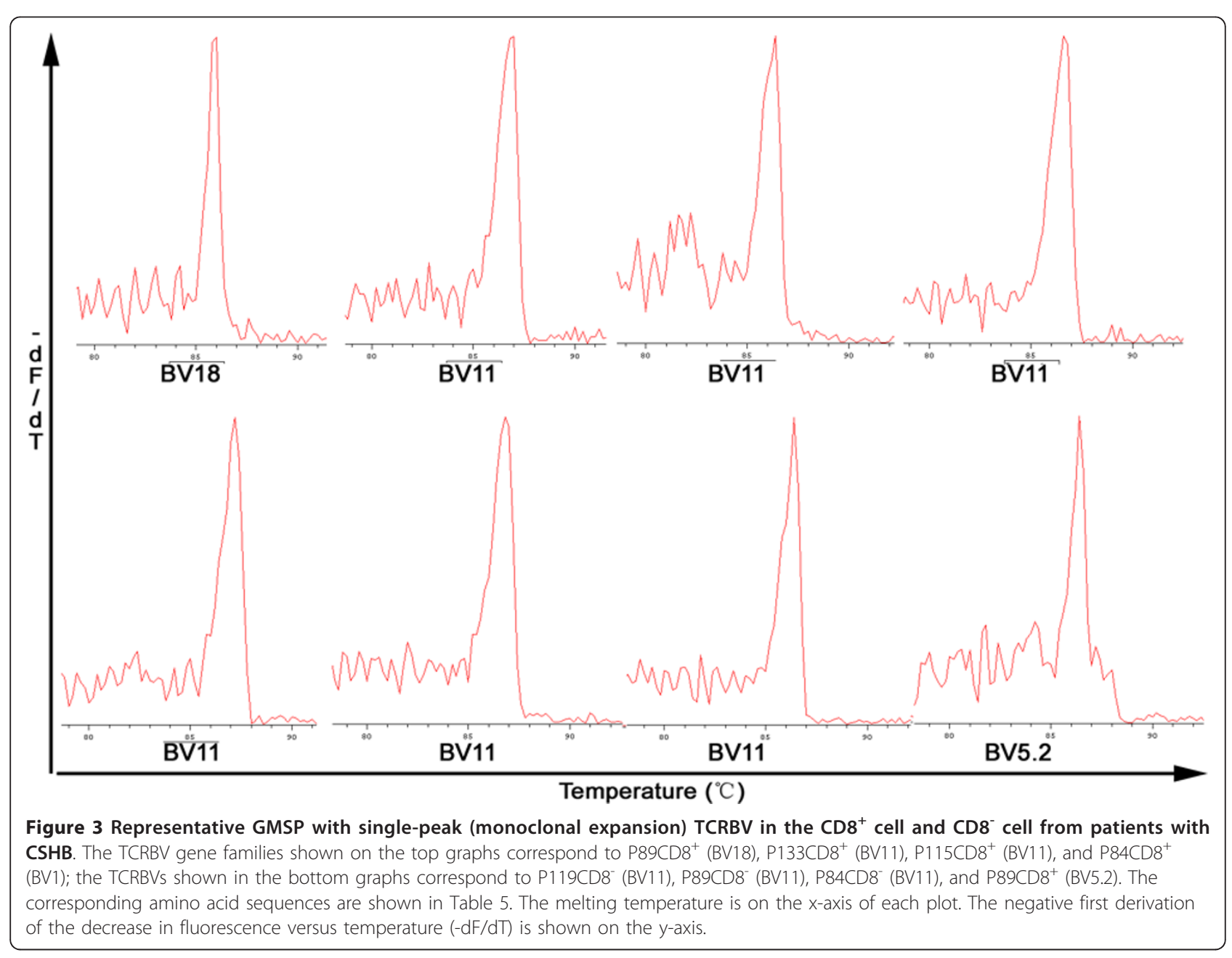


Table 4 Representative amino acid sequences of monoclonal TCRBV families in PBMCs from CSHB patients

\begin{tabular}{|c|c|c|c|c|c|c|}
\hline \multirow{2}{*}{$\begin{array}{c}\text { Patients } \\
69\end{array}$} & \multicolumn{2}{|c|}{ Vbeta } & \multirow{2}{*}{$\frac{\text { CDR3 }}{\text { VEGGNTI }}$} & \multicolumn{2}{|l|}{ BJ } & \multirow{2}{*}{$\begin{array}{l}\text { Ratio } \\
21 / 21\end{array}$} \\
\hline & BV23 & SALYFCASS & & YFGEGSWLTWED & 1.3 & \\
\hline 90 & $\mathrm{~B} \vee 22$ & SAMYFCASS & DLGVAQ & YFGPGTRLTVTED & 2.7 & $9 / 20$ \\
\hline 75 & BV22 & SAMYFCASS & DLGVAQ & YFGPGTRLTVTED & 2.7 & $4 / 18$ \\
\hline 90 & BV18 & SAAYFCASS & RTGDTEA & FFGQGTRLTWED & 1.1 & $21 / 21$ \\
\hline 75 & BV18 & SAAYFCASS & RTGDTEA & FFGQGTRLTWED & 1.1 & $21 / 21$ \\
\hline 105 & BV18 & SAAYFCASS & RTGDTEA & FFGQGTRLTWED & 1.1 & $21 / 21$ \\
\hline 107 & BV11 & SQYLCASS & AGEL & FFGEGSRLTVLED & 2.2 & $5 / 21$ \\
\hline 131 & BV11 & SQYLCASS & AGEL & FFGEGSRLTVLED & 2.2 & $9 / 20$ \\
\hline 138 & BV11 & SQYLCASS & AGEL & FFGEGSRLTVLE & 2.2 & $9 / 18$ \\
\hline 172 & BV11 & SQYLCASS & AGEL & FFGEGSRLTVLED & 2.2 & $3 / 21$ \\
\hline 172 & BV11 & SQYLCATG & VYNEQ & FFGPGTRLTVLED & 2.1 & $4 / 21$ \\
\hline 75 & BV11 & SQYLCATG & VYNEQ & FFGPGTRLTVLED & 2.1 & $7 / 8$ \\
\hline 83 & BV11 & SQYLCATG & VYNEQ & FFGPGTRLTVLED & 2.1 & $20 / 20$ \\
\hline 71 & BV11 & SQYLCATG & VYNEQ & FFGPGTRLTVLED & 2.1 & $21 / 21$ \\
\hline 69 & BV9 & SAVYFCASS & LQAGRGEQ & FFGPGTRLTVLED & 2.1 & $12 / 20$ \\
\hline 172 & BV7 & SALYLCASS & QDSVITGAQ & YFGPGTRLLVLED & 2.5 & $15 / 21$ \\
\hline 90 & BV6 & SAVYLCASS & LAWEEQETQ & YFGPGTRLLVLED & 2.5 & $21 / 21$ \\
\hline 81 & BV5.2 & SALYLCASS & LTAGAYTGEL & FFGEGSRLTVLED & 2.2 & $10 / 22$ \\
\hline 2 & BV5.1 & SALYLCASS & LEWGASYEQ & YFGPGTRLTVTED & 2.7 & $9 / 20$ \\
\hline
\end{tabular}

When the GMSP displayed a single peak (Figure 2), the CDNA of corresponding TCRBV family was re-amplified and PCR product was sequenced after cloning. The amino acid sequences of the max rate of TCRBV families are shown.

GMSP methods were based on qRT-PCR with the gene melting curve technique and developed for detecting the TCRBV gene family as reported in our previous publication [9].

In peripheral blood, the number of $\mathrm{CD}^{+} \mathrm{T}$ cells is approximated 1.5 times greater than the number of the $\mathrm{CD}^{+} \mathrm{T}$ cell; this may impact analysis of TCR repertoire. In this study, we directly analyzed the degree of skewed clonally expanded TCRBV families in purified PBMCs from 27 CSHB patients. We found that the average number of skewed TCRBV families was 5.24, but within the $\mathrm{CD}^{+}$and $\mathrm{CD}^{-}$subsets, the average number was 6.36 and 3.15, respectively. In summary, the number of skewed TCRBV in the CD8- fraction was significantly lower than in the $\mathrm{CD}^{+}$cells. This is consistent with previous reports demonstrating that proliferating $\mathrm{HBV}$ antigen specific $\mathrm{T}$ cells were $\mathrm{CD}^{+} \mathrm{T}$ cells rather than $\mathrm{CD}^{+}$[23]. The skewed TCRBV families among the three cell groups were different, implying that it may be more accurate to analyze the molecular features of the CDR3 motif in sorted T cells. Although the positive selection of $\mathrm{CD}^{+}$cells results in a $\mathrm{CD}^{-}$fraction that contains a residual number of $\mathrm{CD}^{+}$cells and includes B cells, natural killer cells and some mononuclear cells, this "contamination" has relatively little impact on the GMSP profile of the TCRBV CDR3s within the total CD8- cell subset [19].

In recent years, TCR gene transfer has been developed as a reliable method to generate large numbers of $\mathrm{T}$ cells ex vivo with given antigen-specificity and

Table 5 Representative amino acid sequences of monoclonal TCRBV families in $\mathrm{CD8}^{+}$and CD8 ${ }^{-}$cells (depleted CD8 ${ }^{+}$ cells) from CHSB patients.

\begin{tabular}{|c|c|c|c|c|c|c|}
\hline \multirow{2}{*}{$\frac{\text { Patients }^{\mathbf{a}}}{89\left(\mathrm{CD}^{+}\right)}$} & \multicolumn{2}{|c|}{ Vbeta } & \multirow{2}{*}{$\frac{\text { CDR3 }}{\text { RTGDTEA }}$} & \multicolumn{2}{|l|}{ BJ } & \multirow{2}{*}{$\frac{\text { Ratio }}{11 / 11}$} \\
\hline & BV18 & SAAYFCVSS & & FFGQGTRLTWED & 1.1 & \\
\hline $133\left(\mathrm{CD}^{+}\right)$ & BV11 & SQYLCASS & AGEL & FFGEGSRLTVLED & 2.2 & $11 / 20$ \\
\hline $115\left(\mathrm{CD}^{+}\right)$ & BV11 & SQYLCATG & VYNEQ & FFGPGTRLTVLED & 2.1 & $14 / 16$ \\
\hline $84\left(\mathrm{CD}^{+}\right)$ & BV11 & SQYLCATG & VYNEQ & FFGPGTRLTVLED & 2.1 & $27 / 27$ \\
\hline $119\left(\mathrm{CD}^{-}\right)$ & BV11 & SQYLCASS & AGEL & FFGEGSRLTVLED & 2.2 & $14 / 22$ \\
\hline 89 (CD8 $\left.{ }^{-}\right)$ & BV11 & SQYLCATG & VYNEQ & FFGPGTRLTVLED & 2.1 & $18 / 20$ \\
\hline $84\left(\mathrm{CD}^{-}\right)$ & BV11 & SQYLCATG & VYNEQ & FFGPGTRLTVLED & 2.1 & $17 / 20$ \\
\hline $89\left(\mathrm{CD}^{+}\right)$ & BV5.2 & SALYLCASS & LTAGAYTGEL & FFGEGSRLTVLED & 2.2 & $11 / 29$ \\
\hline
\end{tabular}

When the GMSP displayed a single peak (Figure 3), the CDNA of corresponding TCRBV family was re-amplified and PCR product was sequenced after cloning. The amino acid sequences of the max rate of TCRBV families are shown. ${ }^{a}$ The cell subset for analysis in brackets. 
functional avidity, providing great prospects for clinical application [24-29]. TCR re-directed HBV-specific T cells generated from the PBMCs of chronic HBV and HBV-related HCC patients were shown to be multifunctional and capable of recognizing HBV infected cells and HCC tumor cells expressing viral antigens from naturally integrated HBV DNA [30]. Thus, characterization of the HBV-specific T cells, especially their TCR gene usage [31], is essential for the elucidation of the pathogenesis of HBV infection and for the development of individualized treatment.

In the current study, we found that the monoclonal populations expressing TCRBV7 or BV11 molecule were more prevalent compared with other TCRBV families used, regardless of the CDR3 in PBMCs, $\mathrm{CD}^{+}$or $\mathrm{CD}^{-}$ subsets from CSHB patients. We also found the two CDR3 amino acid sequences had conserved motif (BV11, AGEL or VYNEQ and BV7, QDSVTTGAQ), and, among different CSHB patients, the amino acid motifs in the TCRBV22, BV18 and BV11 CDR3 in PBMCs were similar, respectively. At present, although, it is not clear if or how the emergence of the TCRBV families influences the course of CSHB, in a follow-up study, we observed an interesting phenomenon, when CSHB patients expressed the TCRBV11 CDR3 amino acid sequence "AGEL", their short-term response to treatment was better than patients expressing the TCRBV11 CDR3 sequence "VYNEQ". Moreover, the relatively conservative TCRBV gene families may help produce antigen-specific $\mathrm{T}$ cells using TCR gene transfer for the treatment of liver disease.

\section{Conclusion}

In this report, the molecular features of the CDR3 motif in PBMCs and in $\mathrm{CD}^{+}$and $\mathrm{CD}^{-}$subsets isolated from patients with CSHB were explored using GMSP analyses. During inflammatory episodes in patients with HBV infection, the skewed TCRBV in $\mathrm{CD}^{+}$subset was significantly larger than in the $\mathrm{CD}^{-}$subset. This may help to explain the underlying mechanisms of HBV pathogenesis and may be related to impaired viral clearance and repeated HBV infection [32], although, this requires further investigation. The identification of the relatively conserved amino acid sequences of the TCRBV7, BV11 and other member of TCRBV family expressed in this patient population could be used in evaluating the health status of patients with CSHB, and may aid in the development of transduction gene therapy for patients infected with HBV.

\section{Abbreviations}

ALT: alanine amino transferase; AST: aspartate amino transferase; HBV: hepatitis B virus; HBsAg: hepatitis B surface antigen; HBeAg: hepatitis B envelope antigen; CSHB: chronic severe hepatitis B; Real-time-PCR: real-time fluorescent quantitative polymerase chain reaction; GMSP: gene melting spectral pattern.

\section{Acknowledgements}

This work was supported by the Team of Key Science and Technology Innovation of Zhejiang Province (2009R50041), PR China, and the National High-technology R\&D Program of China (2009CB522406).

\section{Author details}

${ }^{1}$ State Key Laboratory for Diagnosis and Treatment of Infectious Diseases, First Affiliated Hospital, College of Medicine, Zhejiang University, Hangzhou 310003, China. ${ }^{2}$ Department of Geriatric, First Affiliated Hospital, College of Medicine, Zhejiang University, Hangzhou 310003, China.

\section{Authors' contributions}

IZ conducted the study, participated in the data collection, performed most experiments, and wrote the initial draft and revised the manuscripts. JQ and HF collected the preliminary data, and helped to perform some experiments. WL and SJ participated in the study design and interpretation of the data. $\mathrm{BH}$ and $\mathrm{HY}$ assisted in experimental design and help to interpret data. $\sqcup$ study coordination and revision of the paper. All authors read and approved the final manuscript.

\section{Competing interests}

The authors declare that they have no competing interests.

Received: 25 August 2011 Accepted: 8 December 2011

Published: 8 December 2011

\section{References}

1. Organization WH: Department of Communicable diseases surveillance and response. Hepatitis B. Who Fact Sheets 2004.

2. Liaw YF: Natural history of chronic hepatitis $B$ virus infection and longterm outcome under treatment. Liver Int 2009, 29(Suppl 1):100-107.

3. Wei L: Natural history of chronic hepatitis B virus infection: what determines prognosis after cirrhotic decompensation? I Gastroenterol Hepatol 2008, 23:1631-1632.

4. Miqueu P, Guillet M, Degauque N, Dore JC, Soulillou JP, Brouard S: Statistical analysis of CDR3 length distributions for the assessment of T and B cell repertoire biases. Mol Immunol 2007, 44:1057-1064.

5. Melenhorst JJ, Lay MDH, Price DA, Adams SD, Zeilah J, Sosa E, Hensel NF, Follmann D, Douek DC, Davenport MP, Barrett AJ: Contribution of TCR- $\beta$ locus and HLA to the shape of the mature human $V \beta$ repertoire. Journal of Immunology 2008, 180:6484-6489.

6. Porter DL, Levine BL, Kalos M, Bagg A, June CH: Chimeric antigen receptor-modified T cells in chronic lymphoid leukemia. N Engl J Med 2011, 365:725-733.

7. Imamura T, Yokosuka O, Kurihara T, Kanda T, Fukai K, Imazeki F, Saisho H: Distribution of hepatitis $B$ viral genotypes and mutations in the core promoter and precore regions in acute forms of liver disease in patients from Chiba, Japan. Gut 2003, 52:1630-1637.

8. Chen Y, Li X, Ye B, Yang X, Wu W, Chen B, Pan X, Cao H, Li L: Effect of telbivudine therapy on the cellular immune response in chronic hepatitis B. Antiviral Res 2011, 91:23-31.

9. Yang JZ, Li MW, Wang JG, Lu HF, Yao XS, He JQ, Li LJ: Rapid detection of clonal expansion of T-cell receptor-beta gene in patients with $\mathrm{HBV}$ using the real-time PCR with DNA melting curve analysis. Hepatol Res 2010, 40:407-414.

10. Yim HJ, Lok AS: Natural history of chronic hepatitis B virus infection: what we knew in 1981 and what we know in 2005. Hepatology 2006, 43: S173-181.

11. McMahon BJ: The natural history of chronic hepatitis B virus infection. Hepatology 2009, 49:545-55.

12. Komatsu H, Inui A, Sogo T, Hiejima E, Tateno A, Klenerman P, Fujisawa T: Cellular immunity in children with successful immunoprophylactic treatment for mother-to-child transmission of hepatitis B virus. BMC Infect Dis 2010, 10:103.

13. Kreslavsky T, Gleimer M, Garbe Al, von Boehmer $\mathrm{H}$ : alphabeta versus gammadelta fate choice: counting the T-cell lineages at the branch point. Immunol Rev 2010, 238:169-181. 
14. Marrack P, Kappler J: Positive selection of thymocytes bearing alpha beta T cell receptors. Curr Opin Immunol 1997, 9:250-255.

15. Okajima M, Wada T, Nishida M, Yokoyama T, Nakayama Y, Hashida Y, Shibata F, Tone Y, Ishizaki A, Shimizu M, Saito T, Ohta K, Toma T, Yachie A: Analysis of $T$ cell receptor Vbeta diversity in peripheral CD4 and CD8 $T$ lymphocytes in patients with autoimmune thyroid diseases. Clin Exp Immunol 2009, 155:166-172.

16. Du JW, Gu JY, Liu J, Cen XN, Zhang Y, Ou Y, Chu B, Zhu P: TCR spectratyping revealed $T$ lymphocytes associated with graft-versus-host disease after allogeneic hematopoietic stem cell transplantation. Leuk Lymphoma 2007, 48:1618-1627.

17. Spicuglia S, Pekowska A, Zacarias-Cabeza J, Ferrier P: Epigenetic control of Tcrb gene rearrangement. Semin Immunol 2010, 22:330-336.

18. Long SA, Khalili J, Ashe J, Berenson R, Ferrand C, Bonyhadi M: Standardized analysis for the quantification of Vbeta CDR3 T-cell receptor diversity. J Immunol Methods 2006, 317:100-113.

19. Pilch H, Hohn H, Freitag K, Neukirch C, Necker A, Haddad P, Tanner B, Knapstein PG, Maeurer MJ: Improved assessment of T-cell receptor (TCR) VB repertoire in clinical specimens: combination of TCR-CDR3 spectratyping with flow cytometry-based TCR VB frequency analysis. Clin Diagn Lab Immunol 2002, 9:257-266.

20. Ochsenreither S, Fusi A, Busse A, Nagorsen D, Schrama D, Becker J, Thiel E, Keilholz U: Relative quantification of TCR Vbeta-chain families by real time PCR for identification of clonal T-cell populations. J Transl Med 2008, 6:34.

21. Seo KS, Park JY, Terman DS, Bohach GA: A quantitative real time PCR method to analyze T cell receptor Vbeta subgroup expansion by staphylococcal superantigens. J Transl Med 2010, 8:2.

22. Sun W, Nie H, Li N, Zang YC, Zhang D, Feng G, Ni L, Xu R, Prasad S, Robinson RR, Ho W, Sercarz E, Zhang JZ: Skewed T-cell receptor BV14 and BV16 expression and shared CDR3 sequence and common sequence motifs in synovial T cells of rheumatoid arthritis. Genes Immun 2005, 6:248-261.

23. Das A, Hoare M, Davies N, Lopes AR, Dunn C, Kennedy PT, Alexander G, Finney H, Lawson A, Plunkett FJ, Bertoletti A, Akbar AN, Maini MK: Functional skewing of the global CD8 T cell population in chronic hepatitis B virus infection. J Exp Med 2008, 205:2111-2124.

24. Kerkar SP, Sanchez-Perez L, Yang S, Borman ZA, Muranski P, Ji Y, Chinnasamy D, Kaiser AD, Hinrichs CS, Klebanoff CA, Scott CD, Gattinoni L, Morgan RA, Rosenberg SA, Restifo NP: Genetic engineering of murine CD8 (+) and CD4(+) T cells for preclinical adoptive immunotherapy studies. J Immunother 2011, 34:343-352.

25. Bendle GM, Haanen JB, Schumacher TN: Preclinical development of T cell receptor gene therapy. Curr Opin Immunol 2009, 21:209-214.

26. A V-R: Control of HIV-1 immune escape by CD8 T cells expressing enhanced T-cell receptor. Nat Med 2008, 14:1390-1395.

27. Wang QJ, Hanada K, Feldman SA, Zhao Y, Inozume T, Yang JC: Development of a genetically-modified novel T-cell receptor for adoptive cell transfer against renal cell carcinoma. J Immunol Methods 2011, 366:43-51.

28. Frankel TL, Burns WR, Peng PD, Yu Z, Chinnasamy D, Wargo JA, Zheng Z, Restifo NP, Rosenberg SA, Morgan RA: Both CD4 and CD8 T cells mediate equally effective in vivo tumor treatment when engineered with a highly avid TCR targeting tyrosinase. J Immunol 2010, 184:5988-5998.

29. Morgan RA, Dudley ME, Wunderlich JR, Hughes MS, Yang JC, Sherry RM, Royal RE, Topalian SL, Kammula US, Restifo NP, Zheng Z, Nahvi A, de Vries CR, Rogers-Freezer LJ, Mavroukakis SA, Rosenberg SA: Cancer regression in patients after transfer of genetically engineered lymphocytes. Science 2006, 314:126-129.

30. Gehring AJ, Xue SA, Ho ZZ, Teoh D, Ruedl C, Chia A, Koh S, Lim SG, Maini MK, Stauss H, Bertoletti A: Engineering virus-specific $T$ cells that target HBV infected hepatocytes and hepatocellular carcinoma cell lines. J Hepatol 2011, 55:103-110

31. Jorritsma A, Schotte R, Coccoris M, de Witte MA, Schumacher TN: Prospects and limitations of T cell receptor gene therapy. Curr Gene Ther 2011, 11:276-287.

32. Hui CK, Leung N, Yuen ST, Zhang HY, Leung KW, Lu L, Cheung SK, Wong WM, Lau GK: Natural history and disease progression in Chinese chronic hepatitis B patients in immune-tolerant phase. Hepatology 2007, 46:395-401. doi:10.1186/1479-5876-9-210

Cite this article as: Yang et al:: Molecular features of the

complementarity determining region 3 motif of the $T$ cell population and subsets in the blood of patients with chronic severe hepatitis B. Journal of Translational Medicine 2011 9:210.

\section{Submit your next manuscript to BioMed Central and take full advantage of:}

- Convenient online submission

- Thorough peer review

- No space constraints or color figure charges

- Immediate publication on acceptance

- Inclusion in PubMed, CAS, Scopus and Google Scholar

- Research which is freely available for redistribution

Submit your manuscript at www.biomedcentral.com/submit
Ciomed Central 